\title{
Morphological and pathogenic properties of Fusarium proliferatum isolates - the causal agent of garlic (Allium sativum L.) rot in Serbia
}

\author{
Maja Ignjatov ${ }^{*}$. Dragana Milošević ${ }^{1}$ Žarko Ivanović ${ }^{2} \cdot$ Maja Karaman ${ }^{3}$. Slobodan Vlajić ${ }^{\text {. }}$ \\ Zorica Nikolić ${ }^{1}$. Jelica Gvozdanović Varga ${ }^{1}$
}

${ }^{1}$ Institute of Field and Vegetable Crops, Maksima Gorkog 30, 21000 Novi Sad, Serbia

${ }^{2}$ Institute for Plant Protection and Environment, Teodora Drajzera 9, 11000 Belgrade, Serbia

${ }^{3}$ University of Novi Sad, Faculty of Sciences, Dositeja Obradovića 2, 21000 Novi Sad, Serbia

\begin{abstract}
Summary: During the past few years, symptoms of garlic clove rot have appeared in storage facilities at different localities in Serbia. Thirteen fungal isolates were isolated from samples of decayed garlic cloves (Allium sativum L.). Based on the colony and fungal morphology, isolated fungi were tentatively identified as F. proliferatum. Pathogenicity of $13 \mathrm{~F}$. proliferatum strains were confirmed by inoculating garlic cloves of Allium sativum (spring cv. Labud, Sedef; winter cv. Bosut, Ranko) and Allium ampeloprasum (cv. Biser). Isolate JBL532 was classified as the most aggressive, while isolate B3 was the least pathogenic. To confirm morphological identification of 13 Fusarium isolates, amplification of TEF-1 $\alpha$ gene was performed using polymerase chain reaction (PCR) with the primer pair: EF1 and EF2. All isolates were cryopreserved at $-80^{\circ} \mathrm{C}$ and deposited in the NCBI GenBank.

Key words: Allium sativum, Fusarium proliferatum, garlic, garlic bulb rot
\end{abstract}

\section{Introduction}

Garlic (Allium sativum L.) is one of the oldest horticultural crops worldwide (Llamas et al., 2013). Garlic production in Serbia covers more than 7000 ha, and it is mostly located in the northern part of country Vojvodina Province (FAO, 2014). Diseased garlic cloves of different varieties were noticed in the storage from 2016 to 2018 in Serbia. Symptoms on garlic appeared as soft, spongy bulbs and cloves covered with white mycelium. Infected bulbs can be brought into a warehouse without any visible disease symptoms, but under the storage conditions the disease develops and leads to garlic rot. According to Fuentes et al. (2013) frequent occurrence of bulbs rot during storage period has become a limiting factor for garlic production worldwide.

The most significant onion and garlic diseases can be caused by different Fusarium species such as F.

Corresponding author:

maja.ignjatov@ifvcns.ns.ac.rs

Acknowledgment

This study was supported by Ministry of Education, Science and Technological Development, Republic of Serbia (Project TR31030). proliferatum, F. oxysporum, F. solani, F. acuminatum and $F$. equiseti (Stanković et al., 2007; Lević et al., 2009; Ignjatov et al., 2017).

Fusarium proliferatum (Matsushima) Nirenberg (teleomorph Gibberella intermedia Kuhlman) has a worldwide distribution and it is the most common global species among the causal agents of garlic bulbs and cloves rot. It is transmitted by seed and soil, and it is possible that garlic cloves and bulbs can be affected after the harvest (Koleva, 2004; Zhao et al., 2014).

Fusarium proliferatum is most likely to be confused with other Fusarium species of Liseola section but it can be differentiated using DNA sequences of the translation elongation factor EF- $1 \alpha$ gene using PCR techniques with primers EF1 and EF2 (Geiser et al., 2004; Leslie \& Summerell, 2006).

In the past few years (2016-2018) Fusarium species were responsible for great crop loss of garlic during storage in Serbia, and a large number of infected garlic samples were collected from storages in different localities in Serbia. The objective of the study was to identify causal agent of garlic clove rot by morphological and molecular identification methods, and to confirm its pathogenicity on different Allium sativum and $A$. ampeloprasum genotypes. 


\section{Materials and Methods}

Isolation and morphological characterization

Twenty-three of garlic samples with symptoms of bulbs and cloves rot were taken from warehouses of different localities in Serbia (Cerić, Đala, Ljuba, Idvor, Sakule, Gložan, Begeč, Pivnice, Farkaždin). For isolation of the causative organism, cloves were separated, peeled off, surface disinfected in $5 \% \mathrm{NaOCl}$ for $2 \mathrm{~min}$, rinsed with sterilized distilled water, dried on a sterile filter paper and small parts $(1 \mathrm{~cm}$ in length) of infected tissues were plated onto the medium surface (Potato Dextrose Agar - PDA) amended with streptomycin sulphate $(300 \mathrm{mg} / \mathrm{l})(\mathrm{w} / \mathrm{v})$. After one week of incubation at $25^{\circ} \mathrm{C}$, fungal isolates were examined visually under a stereoscopic microscope (Carl Zeiss) at $\times 30$ magnification. The spore length and width of 100 conidia from each Fusarium isolate were measured. Thirteen isolates were chosen and sub-cultured using a single spore technique. Morphological characteristics of fungal colonies (mycelia colour, pigmentations in agar, conidia presence) of single-spore isolates cultured onto both PDA and carnation leaf agar (CLA) were characterized using descriptions given by Gerlach \& Nirenberg (1982) and Leslie \& Summerell (2006). The radius of colonies of isolates cultured on PDA was measured after 7 days incubation at $25^{\circ} \mathrm{C}$. The experiment was repeated three times (Prova et al., 2008).

\section{Pathogenicity test}

Pathogenicity test was performed by inoculating the cloves of Allium ampeloprasum (cv. Biser) and Allium sativum (spring cv. Labud, Sedef; autumn cv. Bosut, Ranko) according to Dugan et al. (2007) and Palmero et al. (2012). Cloves were disinfected in $0.5 \% \mathrm{NaOCl}$ for 60 seconds, washed in sterile water, and wounded to a depth of $4 \mathrm{~mm}$ using a $1 \mathrm{~mm}$ diameter probe (Palmero et al. 2012). Each of the 7-day-old fungal cultures grown on PDA were inoculated into five wounded cloves and incubated in a growth chamber at $25^{\circ} \mathrm{C}$ for 3 weeks. For each isolate, another set of five cloves were inoculated with sterile PDA as control. Inoculated and noninoculated cloves were placed in aseptic sealed plastic boxes and incubated for three weeks at $25^{\circ} \mathrm{C}$. After three weeks, the fungi were re-isolated from symptomatic tissues to compare and confirm that the original and the re-isolated fungus were the same.

\section{Molecular identification}

Morphological identification was confirmed using polymerase chain reaction (PCR) with the primer pair: EF1 and EF2 (O'Donnell et al., 1998). To obtain a DNA sequence, a total DNA of the 13 isolates and one positive control FE-3 was extracted directly from the 7 days old mycelium ( $100 \mathrm{mg}$ wet weight), with a Dneasy Plant Mini Kit (Qiagen, Hilden, Germany) according to the manufacturer's instructions. Following DNA extraction, the translation elongation factor 1-alpha gene region was amplified by PCR with the primer pair EF1 (forward primer: 5'-ATGGGTAAGGA(A/G)GACAAGAC-3') and EF2 (reverse primer: 5'- GGA(G/A)GTACCAGT (G/C)ATCATGTT-3') (O'Donnell et al., 1998; Geiser et al., 2004). The amplification was performed on the Eppendorf Mastercycler PCR device, using the following program: 35 repeated cycles: $94^{\circ} \mathrm{C} 1 \mathrm{~min}, 53^{\circ} \mathrm{C} 1 \mathrm{~min}$, $72^{\circ} \mathrm{C} 2 \mathrm{~min}$. The PCR mixture with a total volume of 25 $\mu l$ consisted of $2 \mathrm{x}$ Eppendorf Master Mix (Taq DNA polymerase $1.25 \mathrm{U}, 30 \mathrm{mM}$ Tris- $\mathrm{HCl}, 50 \mathrm{mM} \mathrm{KCl}$, 1.5mM MgCl2; 0.1\% Igepal-CA630; $0.2 \mathrm{mM} \mathrm{dNTP);}$ $0.6 \mu \mathrm{M}$ of each primer, and $1 \mu \mathrm{l}$ of fungal DNA. Amplification fragments were determined using electrophoresis on $1 \%$ agarose gel containing ethidium bromide $(0.5 \mu \mathrm{g} / \mathrm{ml})$. The expected size of the amplified fragments was estimated by comparison with O’RangeRulerTM 100 bp DNA Ladder (SM0623), ready-to-use (Fermentas, Lithuania). The agarose gel was visualised in UV trans illuminator, and the images were captured with DOC PRINT system (Vilbert Lourmat, USA).

Identification of isolates was performed by sequencing the translation elongation factor EF-1 $\alpha$ gene. Purification and sequencing of the amplified fragments were performed in Company MACROGEN, Seoul, South Korea (http://dna.macrogen.com, Korea). Sequences were analysed in the program FinchTV Version 1.4.0., and filed in the GenBank database under the National Center for Biotechnology Information (NCBI) (Tab. 1).

Table 1. List of F. proliferatum isolates from garlic

\begin{tabular}{llll}
\hline $\begin{array}{l}\text { Isolate } \\
\text { Code }\end{array}$ & Locality & NCBI Acc. No. $\begin{array}{l}\text { Colony } \\
\text { type }\end{array}$ \\
\hline B1 & Cerić & KX092460 & Type III \\
B2 & Đala & KX092462 & Type III \\
B3 & Ljuba & KX092463 & Type II \\
B5 & Idvor & KX092461 & Type I \\
BL8 & Sakule & KX611149 & Type II \\
BL9 & Sakule & KX611150 & Type II \\
BL11 & Gložan & KX611147 & Type III \\
BL15 & Begeč & KX611151 & Type III \\
JBL531 & Sakule & KX752415 & Type II \\
JBL532 & Pivnice & KX752416 & Type III \\
JBL535 & Sakule & KX752417 & Type I \\
JBL537 & Farkaždin & KX752418 & Type III \\
JBL6 & Farkaždin & MH161452 & Type III \\
\hline
\end{tabular}




\section{Results}

\section{Isolation and morphological characterization of}

\section{$F$. proliferatum isolates}

Collected diseased garlic cloves showed visible symptoms as dark lesions usually covered with white mycelium followed by necrosis and drying (Fig. 1). The macroscopic characteristics of colonies (colour and morphology of mycelium; pigmentation in agar) showed differences in appearances on PDA incubated at $25^{\circ} \mathrm{C}$, creating three morphologically distinct groups (Type I, Type II and Type III) (Fig. 2). Two isolates (B5, JBL535) with salmon orange pigmentation in agar, and white to light rose fluffy mycelium are classified into a morphological group marked as Type I. Four isolates (B3, BL8, BL9, and JBL531) that produced yellow to light brown pigments mainly in the centre of the colony covered with cotton white, rich mycelium were assigned as Type II. Seven isolated strains (BL1, BL2, BL11, BL15, JBL532, JBL537, JBL6) characterized by white fast growing mycelia and dark violet pigments in medium belonged to a morphological group designated as Type III. The colonies of isolates from group Type II and III were rapidly growing and reached $7-8.5 \mathrm{~cm}$ diameter for 7 days at $25^{\circ} \mathrm{C}$ on PDA, and isolates of group designated as Type I formed colonies of $6.8-7.5 \mathrm{~cm}$ in average for 7 days at $25 \mathrm{C}$.

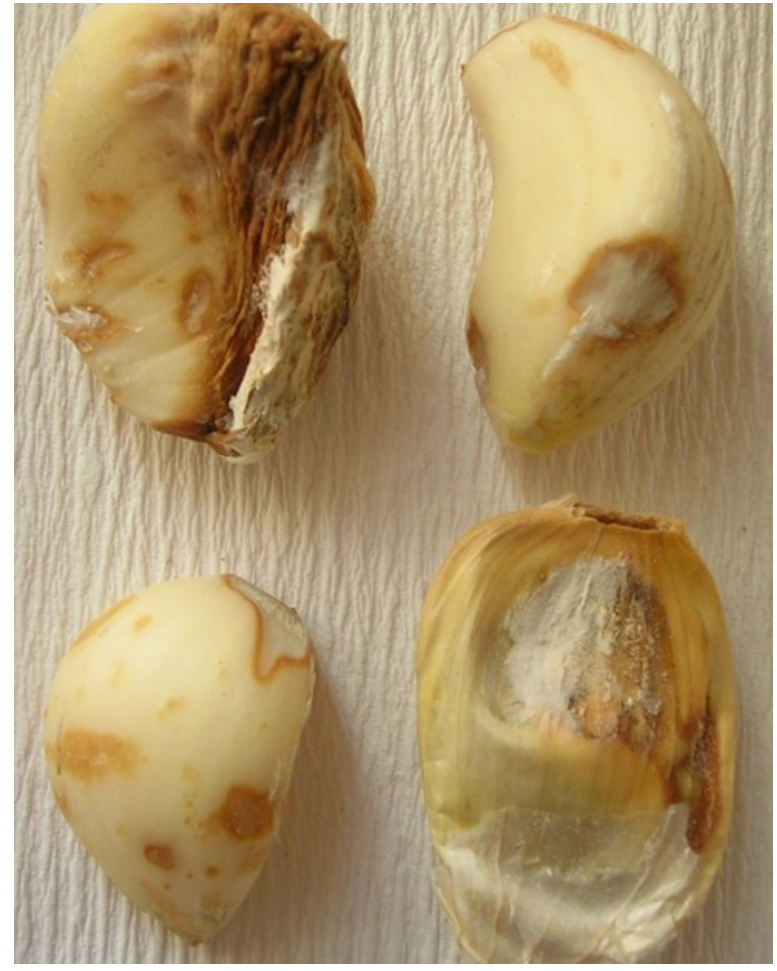

Figure 1. Symptoms of garlic cloves rot

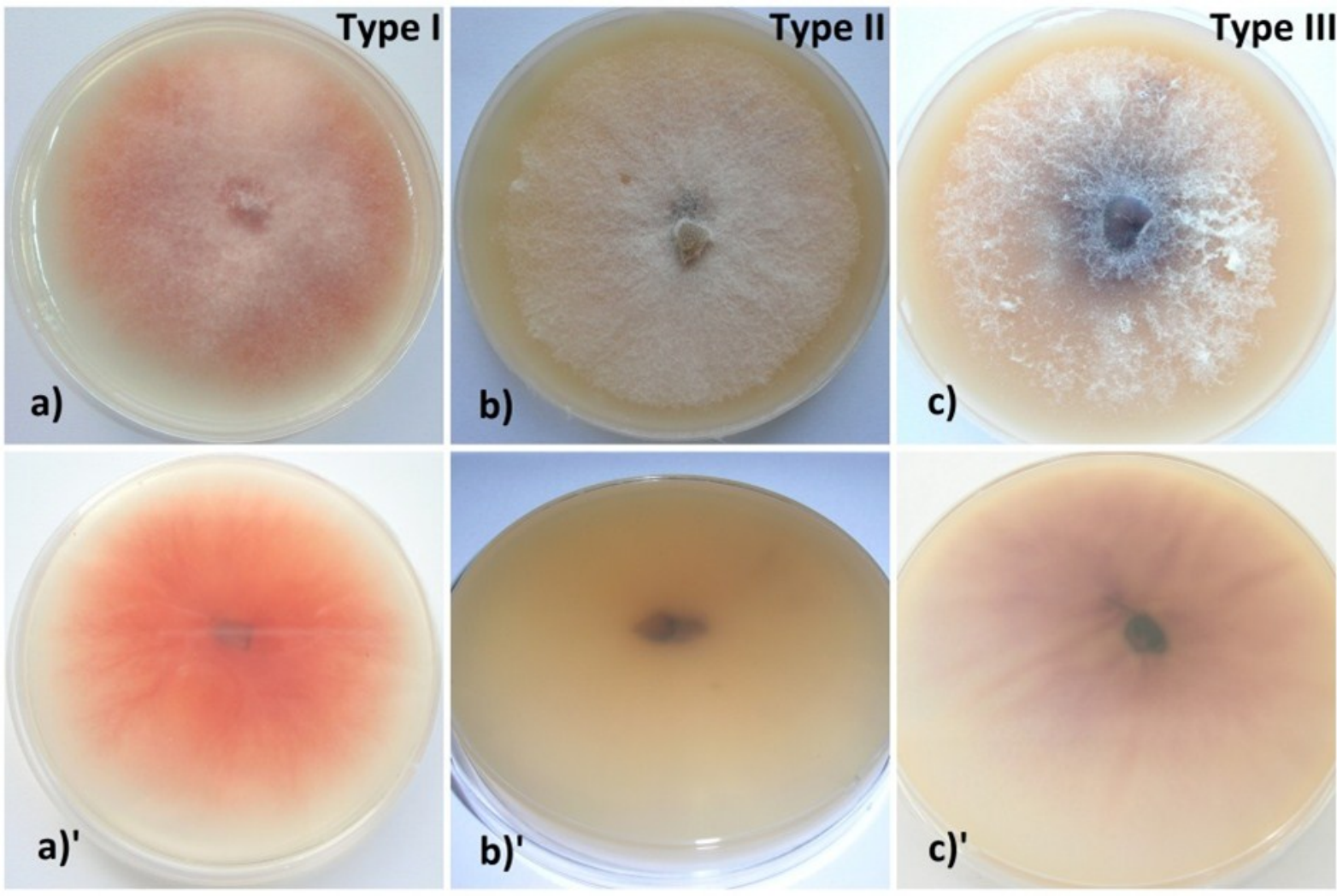

Figure 2. Fusarium proliferatum isolates grown on PDA: a), b), c) Seven-day-old cultures grown on PDA; a)', b)', c)' Pigmentation colony reverse 
All isolates formed one-celled microconidia in chains or cohering in false heads, and slightly curved macroconidia with distinct foot cell, mostly three to five septate, with average dimensions 33-56 $\mu \mathrm{m} \times 3.1-4.0$ $\mu \mathrm{m}$. Chlamydospores were absent.

According to morphological and growth characteristics, all investigated isolates were tentatively identified as F. proliferatum (teleomorph Gibberella intermedia), species of Gibberella fujikuroi complex, Liseola section (Tab. 1).

\section{Pathogenicity test}

Pathogenicity was assessed on all genotypes up to three weeks post inoculation. On the infected garlic cloves, first symptoms started appearing by three days of inoculation as small irregular lesions with aerial mycelium around the wounded tissue. The fastestgrowing isolates JBL532, BL11, and JBL6 caused garlic cloves rot after 8,13 , and 16 days, respectively. The development of symptoms after inoculation with isolate JBL532 was rapid and only eight days after artificial inoculation cloves of all garlic genotypes were completely covered with mycelia, except cv. Ranko. The inoculated garlic tissue became softened, followed by decaying and rotting. Allium sativum (spring cv. Labud, Sedef) and Allium ampeloprasum (cv. Biser) were sensitive to all tested isolates, while the inhibition of mycelial growth was noticed on cv. Ranko. No fungi were recovered from control cloves.

\section{Molecular identification}

The presence of a 700bp amplicon in all investigated isolates was confirmed by comparing the amplified DNA fragments with the marker and positive control. By comparison of the sequences with the Fusarium ID-database, our 13 isolates were identified as F. proliferatum. All isolates were cryopreserved at $-80^{\circ} \mathrm{C}$ and deposited in the NCBI GenBank under Accession Numbers listed in Table 1. Molecular methods and sequencing confirmed previous morphological identification that all isolates belong to $F$. proliferatum with $100 \%$ matches in identity with sequence of $F$. proliferatum (NCBI ID-database JQ762608) as pathogen of garlic in Italy.

\section{Discussion}

This study confirmed the presence of $F$. proliferatum as the causal agent of garlic bulbs and cloves rot during storage. These results are in compliance with those of Stanković et al. (2007) and Lević et al. (2009), who reported that these fungi affect garlic and onion production in Serbia. Diseased garlic cloves presented in this study showed symptoms visible as dark lesions usually covered with white mycelium. Over a longer period of time, infected cloves become necrotic and mummified. Jepson (2008) previously described that garlic plants can be asymptomatic in the field, but bulbs may rot in storage. Tonti et al. (2012) also described the symptoms visible as a brown lesion with the presence of white mycelia after exfoliating infected cloves. Seefelder et al. (2002) described F. proliferatum as causal agent of garlic rot in Germany, as well as Dugan et al. (2003) reported the same disease of garlic in North America, Stanković et al. (2007) in Serbia, Palmero et al. (2008) in Spain and Sankar \& Prasad Babu (2012) in India. Fusarium proliferatum was described by Elshahawy et al. (2017) as the main cause of clove rot during storage, as well as wilt of established garlic plants.

Regarding the appearances fungal colony, three different combinations of colony pigmentation were observed among our isolates. All isolates were divided into three distinguished morphological groups based on the mycelium appearances, and pigmentation in PDA media. Most of the isolated strains belonged to the morphological group designated as Type III. Colonies of this group of isolates were fast-growing, reaching 7 $8.5 \mathrm{~cm}$ in diameter in 7 days at $25^{\circ} \mathrm{C}$ on PDA. Morphological characteristics of $\mathrm{F}$. proliferatum isolates described in this article comply with those given by Gerlach \& Nirenberg (1982). All tested isolates were pathogenic to different $A$. sativum genotypes, as well as A. ampeloprasum (Biser). Garlic cv. Ranko was the most tolerant to all investigated isolates. The most pathogenic isolate to all $A$. sativum tested genotypes including $A$. ampeloprasum was JBL532. First symptoms appeared eight days after artificial inoculation and cloves of all $A$. sativum genotypes were completely covered with mycelia. Palmero et al. (2012) showed that the applied method was suitable for assessing pathogenicity of F. proliferatum isolates on related Allium species. Polymerase chain reaction (PCR) with the primer pair: EF1 and EF2 and frequently used method described by Geiser et al. (2004) confirmed identification and phylogenetic comparison of 13 tested isolates with other Fusarium species.

\section{Conclusion}

Morphological and molecular identification of isolates confirmed that all 13 isolates belong to $F$. proliferatum species responsible for garlic bulbs and cloves rot in Serbia. Pathogenicity of all isolates was confirmed, and the most aggressive isolate was JBL532, while the most tolerant cultivar of $A$. sativum was Ranko. Knowledge of the garlic rot pathogen populations in Serbia is of great importance for development of effective disease management strategies.

\section{References}

Dugan, F.M., Hellier B.C. \& Lupien S.L. (2003). First report of Fusarium proliferatum causing rot of garlic bulbs in North America. Plant Pathology, 52, 426.

Dugan, F. M., Hellier, B. C., Lupien, S. L. (2007). Pathogenic Fungi in Garlic Seed Cloves from the United States and China, and 
Efficacy of Fungicides Against Pathogens in Garlic Germplasm in Washington State. J. Phytopathology, 155, 437-445.

Elshahawy, I.E. Saied N.M. \& Morsy, A.A. (2017). Fusarium proliferatum, the main cause of clove rot during storage, reduces clove germination and causes wilt of established garlic plants. J.Plant Pathol., 99 (1), 85-93.

FAO (Food, Agriculture Organization of the United Nations) (2014). FAOSTAT Production Statistics.

Fuentes, O.Y.M., Delgado Ortiz, J.C., Cerna Chávez, E., Hernández Castillo, F.D., Flores Olivas, A., Gallegos Morales, G., Vázquez Martínez, O. \& Rodríguez Guerra, R. (2013). The first report of Fusarium proliferatum causing garlic bulb rots in Mexico. African Journal of Agricultural Research 8 (6), 570-573.

Geiser, D.M., der mar Jimenez-Gasco, M., Kang, S., Makalowska, I., Veeraraghavan, N., Ward, T.J.; Zhang, N., Kuldau, G.A. \& O'Donnell, K. (2004). FUSARIUM-ID v.1.0: A DNA sequence database for identifying Fusarium. Eur. J. Plant Pathol., 110, 473479.

Gerlach W. \& Nirenberg H. (1982). Mitteilungen aus der Biologischen Bundesanstalt Für Land- und Forstwirtschaft (Berlin - Dahlem), The genus Fusarium - A pictorial atlas, 309:1-405.

Ignjatov, M., Popović, T., Milošević D., Vasić, M., Nikolić, Z., Tamindžić, G., Ivanović, Ž. (2016). Occurence, identification and phylogenetic analysis of Fusarium proliferatum on bean seed (Phaseolus vulgaris L.) in Serbia. Ratar. Povrt., 53(2), 42-45.

Ignjatov, M., Bjelić, D., Nikolić, Z., Milošević, D., Marinković, J., Ivanović, Ž., Gvozdanović-Varga, J. (2017). Morphological and molecular identification of Fusarium tricinctum and F. acuminatum as causal agents of garlic bulbs rot in Serbia. Zbornik Matice srpske za prirodne nauke, 133, 271-277.

Jepson Susan, OSU Oregon State University, Plant Clinic (2008). Fusarium rot of garlic bulbs. http://www.science.oregonstate.edu/ bpp/Plant_Clinic/Garlic/Fusarium.pdf

Koleva, K. (2004). Variety of species and spread of fungi of genus Fusarium related to rotting of garlic. Bulgarian Journal of Agricultural Science, 10, 177-180.

Koch, M. \& Taanami Z. (1995). Occurrence of Fusarium rot of stored garlic in Israel. Plant Disease, 79: 426.

Lević, J., Stanković, S., Krnjaja, V. \& Bočarov-Stančić, A. (2009). Fusarium species: The occurrence and the importance in agricultural of Serbia. Proc. Nat. Sci. Matica Srpska 116, 33-48.
Leslie, J.F. \& Summerell, B.A. (2006). The Fusarium laboratory manual. 1st ed. Blackwell Publishing Ltd; Oxford, London.

Llamas, P., Paton, G., Diaz, G., Serna, G. \& Saez, B. (2013). The effects of storage duration, temperature and cultivar on the severity of garlic clove rot caused by Fusarium proliferatum. J. Postharvest Biol. Technol. 78, 34-39.

O'Donnell, K., Cigelnik, E. \& Nirenberg, H.I. (1998). Molecular systematic and phylogeography of the Gibberella fujikuroi species complex. Mycol., 90, 465-493.

Palmero, D., De Cara, M., Nosir, W., Iglesias, C., García, M., Woodward, S. \& Tello, J.C. (2008). First report of Fusarium proliferatum causing rot of garlic bulbs in Spain. Plant Dis 94, 277.

Palmero, D., De Cara, M., Nosir, W., Galvez, L., Cruz, A., Woodward, S., Gonzalez-Jaen, M.T., Tello, J.C. (2012). Fusarium proliferatum isolated from garlic in Spain: Identification, toxigenic potential and pathogenicity on related Allium species. Phytopathol. Mediterr., 51, 207-218.

Prova, A., Akanda, A. M., Islam, S., \& Hossain, M. M. (2018). Characterization of Sclerotinia sclerotiorum, an Emerging Fungal Pathogen Causing Blight in Hyacinth Bean (Lablab purpureus). The Plant Pathology Journal, 34(5), 367-380.

Sankar, N.R. \& Prasad Babu, G. (2012). First report of Fusarium proliferatum causing rot of garlic bulbs (Allium sativum) in India. Plant Dis 96, 290.

Seefelder, W., Gossmann, M. \& Humpf, H.U. (2002). Analysis of Fumonisin B1 in Fusarium proliferatum infected asparagus spears and garlic bulbs from Germany by liquid chromatographyelectrospray ionization mass spectrometry. J Agr Food Chem 50, 2778-2781.

Stankovic S., Levic J., Petrovic T., Logrieco A. \& Moretti A. (2007). Pathogenicity and mycotoxin production by Fusarium proliferatum isolated from onion and garlic in Serbia. Eur J Plant Pathol 118, 165-172.

Tonti Stefano, Dal Pra Mauro, Nipoti Paola, Prodi Antonio \& Alberti Ilaria (2012). First Report of Fusarium proliferatum Causing Rot of Stored Garlic Bulbs (Allium sativum L.) in Italy. Journal of Phytopathology, 160, 761-763.

Zhao, B., Yan, J., Zhang, S., Liu, X. \& Gao, Z. (2014). Phylogeny and pathogenicity of Fusarium spp. isolated from greenhouse melon soil in Liaoning Province. Saudi Journal of Biological Sciences, 21(4), 374-379. http://doi.org/10.1016/j.sjbs.2013.10.004

\section{Morfološke i patogene odlike izolata Fusarium proliferatum prouzrokovača truleži belog luka (Allium sativum L.) u Srbiji}

\section{Maja Ignjatov · Dragana Milošević · Žarko Ivanović · Maja Karaman · Slobodan Vlajić · Zorica Nikolić · Jelica Gvozdanović Varga}

Sažetak: Tokom proteklih godina u skladištima na različitim lokalitetima u Srbiji pojavili su se simptomi truleži i popadanja belog luka (Allium sativum L.). Izolacijom je dobijeno 13 izolata gljiva roda Fusarium koji su na osnovu morfoloških karakteristika identifikovani kao F. proliferatum. Patogenost izolata je potvrđena inokulacijom različitih genotipova belog luka Allium sativum (prolećne sorte Labud, Sedef, jesenje sorte Bosut, Ranko) i Allium ampeloprasum (sorta Biser). Na osnovu ocene patogenosti, izolat JBL532 se izdvojio kao najagresivniji, dok se izolat B3 pokazao kao najmanje patogen. Morfološka identifikacija potvrđena je amplifikacijom TEF-1 $\alpha$ gena, korišćenjem prajmera EF1 i EF2. Svi izolati se čuvaju na $-80^{\circ} \mathrm{C}$ i deponovani su u NCBI bazu gde su im dodeljeni jedinstveni pristupni brojevi.

Ključne reči: Allium sativum, beli luk, Fusarium proliferatum, trulež belog luka 